\title{
Searching for the bilingual advantage in executive functions in speakers of Hunsrückisch and other minority languages: a literature review
}

\author{
Elisabeth Abreu and Bernardo Limberger (Rio Grande do Sul)
}

\begin{abstract}
The issue of a bilingual advantage on executive functions has been a hotbed for research and debate. Brazilian studies with the minority language Hunsrückisch have failed to replicate the finding of a bilingual advantage found in international studies with majority languages. This raises the question of whether the reasons behind the discrepant results are related to the language's minority status. The goal of this paper was to investigate the bilingual advantage on executive functions in studies with minority languages. This is a literature review focusing on state of the art literature on bilingualism and executive functions; as well as a qualitative analysis of the selected corpus in order to tackle the following questions: (1) is there evidence of a bilingual advantage in empirical studies involving minority languages? (2) are there common underlying causes for the presence or absence of the bilingual advantage? (3) can factors pertaining to the language's minority status be linked to the presence or absence of a bilingual advantage? The analysis revealed that studies form a highly variable group, with mixed results regarding the bilingual advantage, as well as inconsistent controlling of social, cognitive and linguistic factors, as well as different sample sizes. As such, it was not possible to isolate which factors are responsible for the inconsistent results across studies. It is hoped this study will provide an overview that can serve as common ground for future studies involving the issue of a bilingual advantage with speakers of minority languages.
\end{abstract}

\section{$1 \quad$ Introduction}

The presence of cognitive advantages in bilingual individuals has been a worldwide hotbed for research. Ever since the pivotal study by Peal/Lambert (1962), bilingualism has been investigated generally under the premise that it might have positive impacts on cognition. One cognitive domain that is often investigated is executive functions (EF) - "self-directed actions needed to choose goals and to create, enact, and sustain actions toward those goals" (Barkley 2012: 60). A major contribution in that field has come from Ellen Bialystok and her collaborators. This research group, as well as others that were influenced by it, has investigated the potential advantage of bilinguals in executive functions and has suggested that something about the unique bilingual language experience gives rise to improvements in more general cognitive 
processes (e. g. Bialystok et al. 2004; Bialystok/Craik/Luk 2008; Linck/Hoshino/Kroll 2008; Costa/Hernández/Sebastián-Gallés 2008; Costa et al. 2009; Bialystok 2001).

Recent literature reviews call into question the extent of these findings, given the difficulty in replicating the results obtained in Bialystok (Paap/Johnson/Sawi 2015; Paap/Greenberg 2013; Hilchey/Klein 2011; Sanchez-Azanza et al. 2017; Duñabeitia/Carreiras 2015). This has given rise to criticism and has indicated the need to re-evaluate methodological and contextual factors that potentially cloud results. One of these aspects has been the specificities of different bilingual populations, such as minority groups.

Minority languages can be characterized in terms of their minoritized social and economic functions (Grenoble/Roth Singerman 2016). Studies investigating the bilingual advantage in speakers of minority languages are not numerous, compared with the wider scope of the field. Nevertheless, the unique set of cultural and social dimensions found in minority languages means that studies targeting them have the potential of revealing blind spots in the literature.

In Brazil, there have been studies with speakers of minority languages, trying to replicate the finding of a bilingual advantage in executive functions. The most frequently studied language in Brazil is Hunsrückisch, a variety of German spoken in southern regions of the country, as well as in Argentina and Paraguay (Altenhofen 2013). Studies with Hunsrückisch report limited or absent EF advantages in bilinguals. This raises the question of which factors might be responsible for this discrepancy when compared to international studies (Limberger/Buchweitz 2012).

Hunsrückisch has been thoroughly documented and described in linguistic, social, and cultural characteristics (Altenhofen 1996; Altenhofen 2017; Altenhofen/Frey 2006). This fact, when combined with the existence of a somewhat homogenous group of studies, means that Hunsrückisch can provide an initial framework from which to analyze studies with minority languages.

This paper is a literature review and qualitative analysis targeting executive functions and bilingualism in the context of minority languages. The discussion tackles the following questions:(1) is there evidence of a bilingual advantage in empirical studies involving minority languages? (2) are there common underlying causes for the presence or absence of the bilingual advantage? (3) can factors pertaining to the language's minority status be linked to the presence or absence of a bilingual advantage?

The framework for the analysis of factors related to the minority status of the languages draws from Brazilian studies with Hunsrückisch. These studies have raised numerous questions regarding use, scope, among other factors. For this paper, we chose to systematize the discussion in terms of: (1) participants' age and socioeconomic status; (2) the tasks used in each study; (3) the context of use of the minority language in question, if mentioned, with emphasis given to written and academic use and official status; (4) main outcome of the study.

If the characteristics of a minority language play a significant role in determining the presence of a bilingual advantage, then there is also an absence of a bilingual advantage in the international studies, but it might be other factors in the context and scope of use of minority languages 
that restrict or otherwise affect the extent of a bilingual advantage. Such factors include the other contexts of use, written language use, as well as socioeconomic status of speakers.

This paper is so divided: Section 2 consists of a brief review of the field of bilingualism and executive functions and a summary of the bilingual advantage hypothesis, as well as recent criticism targeted at it. Section 3 is comprised of a brief review of Brazilian studies on the bilingual advantage in speakers of Hunsrückisch, providing the necessary framework for the discussion. Section 4 contains a more detailed description of the methods used in this paper. Section 5 includes both the description of the selected papers in each corpus, focusing on selected characteristics, as well as a discussion of the findings. In Section 5 of this paper there are considerations focused on future studies as well as issues concerning the limitations of this review.

\section{The bilingual advantage in executive functions}

The term "executive function" (EF) refers to a complex cognitive construct that involves a set of processes underlying controlled, goal-directed responses to novel or difficult situations (Hughes 2005). Miyake et al. (2000) propose that the three primary EF would be mental set shifting, information updating and monitoring and inhibition of prepotent responses. According to the authors, EF may be separable, but they are related constructs. They are also essential for cognitive processes and behavioral competencies that are associated with the performance of goal-related behavior (Gazzaniga/Ivry/Mangun 2014); for instance, the ability to perform tasks that involve suppression of unnecessary or distracting streams of information while focusing on one source of pertinent information involves executive function.

The hypothesis of a potential bilingual advantage in EF arises from the notion that both languages in a bilingual's mind are possibly active (Grosjean 2008). According to the model of inhibitory control proposed by Green (1998), language coactivation would demand a pattern of selection and inhibition of one language over the other, potentially producing enhanced cognitive control extending to other cognitive domains.

A major contribution to the testing of this hypothesis has come from the work of Bialystok and her collaborators. According to representation and control model (Bialystok 2001), it would be expected that bilingualism had a more significant enhancing effect on control - that is, selective attention and inhibition of irrelevant information.

The bilingual advantage hypothesis suggests that bilinguals have enhanced cognitive control in comparison to monolingual peers. The underlying mechanism behind the proposed bilingual advantage stems from the necessity of inhibiting one language while activating the target language in oral production (Green 1998). The subsequent effect of this exercise would be, then, enhanced cognitive control that extends beyond language. One issue that could be raised with this proposed mechanism is that it should not be equally effective in communities where codeswitching is abundant. In the case of Hunsrückisch, where in most cases the entirety of the community is bilingual and therefore code-switching is constant, one would expect to find no sign of an advantage. However, studies have not shown consistent results (e. g. Billig 2009; Pinto 2009). 


\subsection{Criticism on the bilingual advantage}

The hypothesis of a bilingual advantage is not without controversy. Recent publications have questioned the extent or even the existence of an advantage at all. Sanchez-Azanza et al.'s (2017) bibliometric analysis of studies from 2005 to 2015 revealed an increase in publications challenging the bilingual advantage hypothesis in the period between 2014 and 2015. Although this is likely linked to the pivotal article by Paap/Greenberg (2013), Sanchez-Azanza et al. (2017:8) also point to the possibility of there being studies challenging the bilingual advantage before that period, and that might not have been published due to bias favouring positive results in research on the topic.

The present review does not intend to provide a comprehensive list of all papers challenging the bilingual advantage hypothesis. Rather, by presenting significant criticism on this hypothesis, we hope to find potential causes for inconsistencies in results regarding the bilingual advantage. It is important to regard criticism and evidence against this hypothesis as it could help understanding what exactly causes some experiments to show significant differences between monolinguals and bilinguals, while others do not, as already underscored by Duñabeitia/Carreiras (2015).

A significant contribution to this discussion has come from literature reviews. Hilchey/Klein (2011) examined studies which utilized the Simon task, the Simon arrow task, the Stroop task, or the Attentional Network Task, in terms of outcomes, pairing of SES and tasks used. Their analysis revealed that the interference effect advantages for bilinguals are rare both in children and young-adults, and more substantial, although inconsistent, in middle-aged and elderly adults.

Paap/Johnson/Sawi's (2015) comprehensive review of empirical studies provided substantial evidence that bilingualism either has null effects on EF as a whole, or only has benefits under very specific circumstances. The review discusses a number of issues in previous publications, amongst which we highlight: (1) potential publication bias favouring studies with positive or mixed results regarding the bilingual advantage; (2) multiple studies with small sample-sizes that might inflate the rate of false-positive results; (3) the presence of confounding variables that might equally impact $\mathrm{EF}$, such as socioeconomic status, cultural differences, and genetic differences; (4) issues with statistical modelling and processing; (5) low rates of replication of seminal studies.

Paap et al. (2018) add to the discussion by revisiting Bialystok`s revised hypothesis for the mechanism underlying the bilingual advantage. Paap et al (2018) hypothesize a conflict-resolution construct named attentional control, which could have a significant role in bilingual language control. Nevertheless, the problem remains that the exact mechanism is ill defined, and therefore needs further testing which differentiates between attentional selection tasks and other types of conflict resolution, such as inhibition. The revised hypothesis predicts that only tasks relying only on attentional control would show a bilingual advantage.

\subsection{The case of minority languages}

Bilingualism is a highly variable phenomenon. One way to categorize bilinguals is in terms of (1) degree of bilingualism, (2) context of acquisition, (3) age of acquisition, (4) social 
orientation and (5) domain of use (Chin/Wigglesworth 2007). Even within these limited criteria, it is already possible to envision the complex net of interactions that makes bilingualism highly heterogeneous.

Minority languages are very often linked with bilingualism, as it is increasingly unlikely to find monolingual speakers of a minority language. A minority language has been defined by the European Charter for Regional and Minority Languages (Council of Europe 1999) as a language that is different from the official language of a given state, and that are traditionally used within a certain region of this state by a group smaller than the rest of the population (Pasikowska-Schnass 2016). In the case of this paper, it is necessary expand on this definition, as it does not tackle minority languages of immigrant origin, such as is the case of Hunsrückisch. Altenhofen (1996) defines Hunsrückisch as a marginal language due to its restricted scope of use in familiar and neighbouring spaces. Moreover, Portuguese is the official language of most Brazilians (the only other official language being Brazilian sign language), and as such it is used in media, formal education and legal matters. Portuguese, thus, is in a clear majority position when contrasted with Hunsrückisch.

Minority languages do not constitute a homogenous group of languages: while some might share co-official status with the majority language in their respective regions and be present, for example, in educational or formal contexts; others have a more restricted scope. Nevertheless, some characteristics arguably unify these languages as a group. Allardt (1984) names four basic criteria to determine a minority language: (1) self-categorization (self-ascription); (2) common descent; (3) distinctive traits, be it linguistic, social or historical, that are related to the language (4) social organization of the interaction of language groups that puts the speakers of this language in a minority position.

An additional issue that needs to be tackled is the similarities and distinctions between dialects and minority languages. In some ways, both groups might share characteristics such as limited written use and absence in formal and written instances. Another significant reason to include this discussion is that there have been recent studies tackling bilectalism and EF.

Minority languages and dialects are both marked by the presence of some sort of subordination, although the underlying mechanisms of said subordination differ (Allardt 1984: 196). Altenhofen (2013) places minority languages in contrast to majority languages, where the latter play the role of what is "common" and "ordinary". Minority languages, thus, have a marginalized position. Similarly, the term "dialect" refers to an informal, lower-class or rural variety which has a language as its superordinate (Haugen 2001: 101). This widespread definition puts dialects as something other than a language, and that alone is a form of marginalization. The term "dialect" might therefore carry a depreciative undertone, when in fact it should be defended that this is not be case, as a dialect is a language (Coseriu 1982).

A distinction that seems to arise when comparing minority languages and dialects is the degree of similarity between the minority language/dialect and the majority language. Dialects are seen as a variety of a majority language, and as such there tends to be a degree of similarity between the two that is not necessarily present in case of a minority language. 


\section{Brazilian studies with Hunsrückisch: a framework for the analysis of studies with minority languages}

Hunsrückisch provides a useful basis for comparison with other minority languages. Some reasons for this are: (1) Hunsrückisch has been thoroughly described, which means there is sufficient information about context and scope of use, (2) there have been comparatively more studies about this language concerned with effects of bilingualism on executive functions than other minority languages, (3) the group of studies raises numerous questions, which provides a basis for analyzing other studies with minority languages (4) this corpus of studies, as well as most information about this minority language is only available in languages other than English, which means that so far there has been little to no integration with international studies.

Hunsrückisch (hunsriqueano, in Portuguese) is an immigrant language, having arrived in southern Brazil with German immigrants from 1824 onwards (Altenhofen/Frey 2006). Its origins can be traced back to Rhine-Franconian and Mosel-Franconian bases, although it has since then developed through contact with Portuguese and with other German varieties (Altenhofen 1996: 26). Hunsrückisch exists in multiple regions of South America, with a greater concentration of speakers in the southern states of Brazil, as we can see on the following map (Figure 1), which also shows other minority languages of German origin in South America.

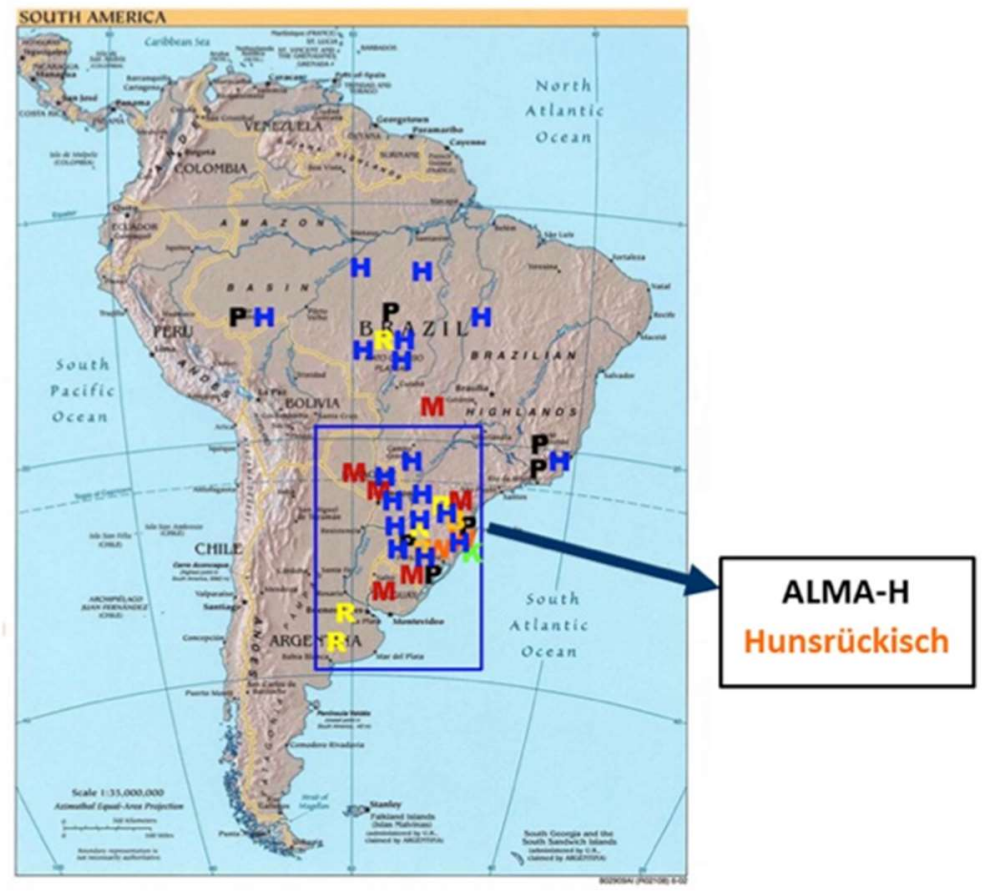

Figure 1: Map of Hunsrückisch and other minority languages in South America (Althofen 2017) ${ }^{1}$

Hunsrückisch is used almost exclusively within the context of family or community (Altenhofen/Frey 2006). It does not have a widespread written use, and Standard German is the standard variety in use, although its use has declined with time (Steffen/Altenhofen 2014). The use of Hunsrückisch is in decline, and from 1986 to 2009 the number of speakers is estimated to have dropped by two million (Souza/Damke 2014).

\footnotetext{
${ }^{1}$ Legend: H: Hunsrückisch; B: Bohemian/Bavarian/Bukovinian; K: Kaffeeflickersch; M: Mennonites Plautdietsch; R: German Russian language; P: Pomeranian (Altenhofen 2017).
} 


\subsection{The existing literature}

The general finding in the literature is that bilingual speakers of Hunsrückisch do not have an advantage when compared to monolingual speakers of Portuguese (Billig 2009; Pinto 2009; Kramer 2011; Brentano 2011; Limberger 2014; Billig 2014). Interestingly, Brentano (2011) and Kramer (2011) found an advantage only in Portuguese-English bilingual groups, but not in groups of Hunsrückisch speakers. This might indicate that factors intrinsic to the use of Hunsrückisch or to its context might be causing this difference. Similarly, multilinguals (speakers of Portuguese, Hunsrückisch and Standard German) in Limberger (2014) had shorter global reaction time than monolinguals in the ANT task whereas bilinguals (Portuguese/Hunsrückisch) did not.

\subsection{Questions raised by the literature}

\subsubsection{Participants' age and socioeconomic status}

Most studies (Pinto 2009; Billig 2009; Kramer 2011; Billig 2014; Limberger 2014) were conducted with adults or older adults, apart from Brentano (2011). Hunsrückisch, like many minority languages, has a greater number of older adult speakers, and amongst speakers, they are the ones who show greater frequency of use. For instance, Pinto (2009) reports that in the elderly group the proportion of time spent speaking was $43 \%-57 \%$ (Hunsrückisch - Brazilian Portuguese), while in the young adult group the use of Hunsrückisch was only $31 \%$ (ibid. 57).

Occupation also varies with age, with retirement playing a significant role. Interestingly, linguistic groups also seem to show variation in that regard. Pinto (2009) reports that twice as many monolingual older adults in her study were professionally active when compared to the bilingual group, a factor that directly impacts daily demands in terms of mathematics, writing and computer use (ibid. 88). In terms of education, Kramer (2011) also addresses amongst younger bilinguals, the average time in years of education was 13.4 years, whereas adult bilinguals had an average of 12.8 years and older bilinguals, 5.3 years.

Socioeconomic and education-related variables sometimes show a degree of correlation with the participants 'linguistic group. Brentano (2011) describes the socioeconomic distinctions between the monolingual (Portuguese), the school-bilingual (Portuguese/English) and the familybilingual (Hunsrückisch/Portuguese) groups: school-bilinguals come from a higher class, family-bilinguals from middle class, and monolinguals from a generally lower class. Brentano (2011) also describes how children in the school-bilingual group had 50\% more weekly school hours than the family bilingual group (30 weekly hours against 20 )

\subsubsection{The Tasks used}

Standardized tests are widely present in this group of studies. The following tasks were used: Simon Task 1, Simon Squares (Billig 2009); Simon Task 2 (Pinto 2009; Kramer 2011); Stroop Task (Billig 2009; Brentano 2011); Simon Arrow Task (Kramer 2011; Brentano 2011); Attention Network Task (Limberger 2014; Billig 2014). In all cases, tasks were computer-based. While this is a common feature in the field, it begs the question of how to accommodate ecological adequacy, considering the aforementioned issues of educational and socioeconomic background. For example, Billig (2009) reports that only two bilinguals and one monolingual 
in the elderly group (42 participants) used the computer frequently (ibid: 76), while the rest did not feel comfortable with the interface during testing (ibid: 103).

Another important issue concerning the use of standardized testing in speakers of minority languages is the language of testing, and whether this is delivered through spoken or written modality. This is relevant considering that some minority languages do not have a standardized written form and are detached from formal contexts such as the assessment through cognitive tasks.

\subsubsection{Context of use}

As stated at the start of this section, Hunsrückisch has no widespread written use, and its context of use is restricted to familial and informal contexts. Studies corroborate with this view and add details and questions that might be of interest in that they can be applied to other minority languages.

Given that communities where Hunsrückisch is spoken are for the most part bilingual, day-today communication includes extensive code-switching (Pinto/2009). Interestingly, Portuguese seems to be the dominant language in terms of use amongst speakers: (Billig/2014) reports that participants spend only $30 \%$ of their weekly time using Hunsrückisch; (Pinto/2009) reports that, on average, participants spent at least 3,87 hours speaking Hunsrückisch, compared to 5,2 hours speaking Brazilian Portuguese; (Limberger/2014) reported 34\% of time using Hunsrückisch in daily life amongst bilinguals, and 25\% amongst multilinguals. As stated before, older generations tend to spend more time using the minority language, something that might also be influenced by occupational and educational demands.

Regarding the presence of written use, Limberger (2014: 66) points out that, while Hunsrückisch is essentially a spoken language, there have been attempts in establishing a written system for it, most notably ESCRITHU (Altenhofen et al. 2007) and Hunsrik Wiesemann (2008). Pinto (2009: 56) indeed reports that 10\% of participants, both elderly and young adults, read or write in Hunsrückisch. Young adult bilinguals read less than an hour Hunsrückisch a day, compared to $2,87 \mathrm{~h}$ in Brazilian Portuguese. Older bilinguals read approximately $20 \%$ in Hunsrückisch and $80 \%$ in Brazilian Portuguese whereas in young bilinguals the proportion is $17 \%-83 \%$, respectively. Regarding the content of texts in Hunsrückisch are mostly religious texts, as well as newspapers and magazines.

An aspect related to the limited written modality is the complete absence of Hunsrückisch in formal education. It was unanimously reported that Hunsrückisch is not present in a formal educational context. Brentano (2011) describes the presence of the language as being restricted to interactions between colleagues in school, but not extending to classroom per se. Additionally, she reports the presence of Standard German classes once a week (ibid.79). This scenario can be traced back, according to Altenhofen (2004), to a nationalization policy which began in 1938 during the Estado Novo regime in Brazil. This policy restricted the use of immigrant languages in Brazil and established Portuguese as the single language to be used in formal education. 


\section{$4 \quad$ Methods}

This paper is a literature review consisting of a qualitative analysis of studies concerning the effects of bilingualism on executive functioning in speakers of minority languages. The search focused on international studies on regional languages and their effects on executive functions. The framework for the qualitative analysis was provided by data and discussions from Brazilian studies with the minority language Hunsrückisch.

We selected papers for the corpus of analysis considering the following inclusion criteria: (1) peer review and papers; (2) behavioral studies; (3) studies with speakers of a minority language. Papers were selected from the following databases: PMC (PubMed Central), Lilacs (Literature in the Health Sciences in Latin America and the Caribbean), ScienceDirect (Elsevier), APA PsycNET (American Psychological Association). In the search, we utilized the following index words ((minority languages OR dialects OR bilectalism) AND executive functions).

We excluded studies with clinical populations; with only monolingual groups; and neuroimaging studies, as these are beyond the scope of our analysis. After reading the titles of the articles found with these index words, we selected the papers that meet the inclusion criteria. Then we excluded repeated papers and read the abstracts to excluding studies that do not belong to the scope of our investigation. After reading the papers, we looked for the references in the selected papers and selected some additional papers that tap into the inclusion criteria of the corpus, because there may be not many articles in the field.

In the discussion, we analyze the selected studies in terms of the following features: (1) participants' age and socioeconomic status; (2) the tasks used; (3) the context of use of the minority language in question, if mentioned, with emphasis given to written and academic use and official status; (4) main outcome of the study. Aspects 1 to 3 were selected based on discussions found in Brazilian literature with the minority language Hunsrückisch. Upon analyzing the differences and similarities on these criteria and in light of the collected data, we propose answers to the main research questions: (1) is there evidence of a bilingual advantage in empirical studies involving minority languages? (2) are there common underlying causes for the presence or absence of the bilingual advantage? (3) can factors pertaining to the language's minority status be linked to the presence or absence of a bilingual advantage?

\section{$5 \quad$ Results and discussion}

The search took place in October 2019 and was a little diffuse at first, as it resulted in 940 papers. This could be a result of the lack of coherence in the nomenclature of minority languages, or of the limited number of studies investigating or discussing the topic. After reading the title of all papers, we selected 30 papers that match the criteria. Then, we read the abstract and excluded the repeated papers. Afterwards, we selected eight papers that tapped into the criteria. The final sample is composed of these papers and eight papers selected of the author's databases because we consider them important for the research field, and they did not appear in the searches. In the following table, we present the international studies with minority languages that we selected for review and discussion. 


\begin{tabular}{|c|c|c|c|c|}
\hline Study & Participants & $\begin{array}{l}\text { Minority } \\
\text { language, } \\
\text { country }\end{array}$ & Tasks & Main outcomes \\
\hline $\begin{array}{l}\text { Costa/Her- } \\
\text { nández/Se- } \\
\text { bastian-Gal- } \\
\text { lés (2008) }\end{array}$ & $\begin{array}{l}\text { Adults (100 BL and } 100 \\
\text { ML, MA: 22) }\end{array}$ & Catalan, Spain & $\begin{array}{l}\text { Attention Net- } \\
\text { work Task } \\
\text { (ANT) }\end{array}$ & $\begin{array}{l}\text { BL advantage on global } \\
\text { RT and conflict effect }\end{array}$ \\
\hline $\begin{array}{l}\text { Lauchlan/ } \\
\text { Parisi/Fadda } \\
\text { (2013) }\end{array}$ & $\begin{array}{l}\text { Children from Scotland } \\
(30 \text { BL and } 30 \text { ML, } \\
\text { MA: } 10) \text { and from Sar- } \\
\text { dinia ( } 32 \text { BL and } 29 \\
\text { ML, MA: } 10)\end{array}$ & $\begin{array}{l}\text { Scottish Gaelic, } \\
\text { Scotland } \\
\text { Sardinian, } \\
\text { Italy }\end{array}$ & $\begin{array}{l}\text { WISC subtests: } \\
\text { (a) Block Design } \\
\text { (b) Digit Span } \\
\text { (c) Vocabulary } \\
\text { (d) Arithmetic }\end{array}$ & $\begin{array}{l}\text { Scottish BL advantage } \\
\text { on the blocks subtest; } \\
\text { Scottish BL outper- } \\
\text { formed the other three } \\
\text { groups on (c) and (d) } \\
\text { subtests; BL advantage } \\
\text { in Sardinia in all subtests }\end{array}$ \\
\hline $\begin{array}{l}\text { Duñabeitia et } \\
\text { al. (2014) }\end{array}$ & $\begin{array}{l}\text { Children and adoles- } \\
\text { cents }(252 \mathrm{BL}, \mathrm{MA}: 11 \\
\text { and } 252 \mathrm{ML}, \mathrm{MA}: 11), \\
\text { divided into six age sub- } \\
\text { groups }\end{array}$ & Basque, Spain & $\begin{array}{l}\text { Classic Stroop } \\
\text { Task; Numerical } \\
\text { Stroop } \\
\text { Task }\end{array}$ & No BL advantage \\
\hline $\begin{array}{l}\text { Antón et al. } \\
(2014)\end{array}$ & $\begin{array}{l}\text { Children (180 ML and } \\
180 \text { BL, MA: 10) }\end{array}$ & Basque, Spain & $\begin{array}{l}\text { Child Attention } \\
\text { Network Task } \\
\text { (ANT) }\end{array}$ & No BL advantage \\
\hline $\begin{array}{l}\text { Gathercole et } \\
\text { al. }(2014)^{2}\end{array}$ & $\begin{array}{l}\text { Children: }(3,4,5,8 \text { and } \\
\text { 15) and adults, (MA: } \\
67), 3 \text { groups: Welsh at } \\
\text { home, Welsh and Eng- } \\
\text { lish, or only English }\end{array}$ & $\begin{array}{l}\text { Welsh, Wales } \\
\text { (UK) }\end{array}$ & $\begin{array}{l}\text { Card sort tasks; } \\
\text { Simon task (one } \\
\text { adult version and } \\
\text { one child ver- } \\
\text { sion) }\end{array}$ & $\begin{array}{l}\text { No BL advantage on all } \\
\text { age groups }\end{array}$ \\
\hline $\begin{array}{l}\text { De Bruin/ } \\
\text { Bak/Sala } \\
(2015)\end{array}$ & $\begin{array}{l}\text { Older adults (28 active } \\
\text { BL, } 24 \text { inactive } B L \text { and } \\
24 \text { ML, MA: } 71)\end{array}$ & $\begin{array}{l}\text { Gaelic, } \\
\text { Scotland }\end{array}$ & $\begin{array}{l}\text { Simon arrow } \\
\text { task; Task- } \\
\text { switching para- } \\
\text { digm }\end{array}$ & No BL advantage \\
\hline $\begin{array}{l}\text { Garraffa/ } \\
\text { Bevridge/ } \\
\text { Sorace } \\
(2015)\end{array}$ & $\begin{array}{l}\text { Children ( } 45 \mathrm{ML} \text { and } 40 \\
\text { BL). Each group was } \\
\text { subdivided into } 2 \text { age } \\
\text { groups: } \\
(1) 1^{\text {st }} \text { year of Italian } \\
\text { primary school: ML }= \\
\text { 20, MA: } 7 ; \mathrm{BL}=18 \text {, } \\
\text { MA: 7) } \\
\text { (2) } 2^{\text {nd }} \text { year (ML }=25 \text {, } \\
\text { MA: } 8 ; \mathrm{BL}=22, \mathrm{MA}: \\
8)\end{array}$ & $\begin{array}{l}\text { Sardinian, } \\
\text { Italy }\end{array}$ & $\begin{array}{l}\text { Opposite world } \\
\text { task; Dimen- } \\
\text { sional change } \\
\text { card sort task } \\
\text { (DCCS) }\end{array}$ & $\begin{array}{l}\text { Overall BL advantage; } \\
\text { global improvement } \\
\text { from younger to older } \\
\text { children }\end{array}$ \\
\hline $\begin{array}{l}\text { Antón et al. } \\
\text { (2016) }\end{array}$ & $\begin{array}{l}\text { Study 1: Seniors (24 BL } \\
\text { and } 24 \text { ML), Study 2: } \\
\text { ( } 70 \text { BL, who vary in } \\
\text { their L2 mastery, MA: } \\
69 \text { ) }\end{array}$ & Basque, Spain & $\begin{array}{l}\text { (1) Verbal Stroop } \\
\text { Task; (2) Numer- } \\
\text { ical } \\
\text { Stroop } \\
\text { Task }\end{array}$ & $\begin{array}{l}\text { Study 1: No BL ad- } \\
\text { vantage } \\
\text { Study } 2 \text { : No modulation } \\
\text { in any of the indices due } \\
\text { to L2 proficiency. }\end{array}$ \\
\hline
\end{tabular}

\footnotetext{
${ }^{2}$ In this study the authors also applied a metalinguistic task. As the task falls outside the scope of the paper, we
} did not report it. The same was done in all other similar instances. 


\begin{tabular}{|c|c|c|c|c|}
\hline Study & Participants & $\begin{array}{l}\text { Minority } \\
\text { language, } \\
\text { country }\end{array}$ & Tasks & Main outcomes \\
\hline $\begin{array}{l}\text { Antoniou et } \\
\text { al. (2016) }\end{array}$ & $\begin{array}{l}\text { Children (64 BD and } 47 \\
\text { MTL - bilectal and } \\
\text { English speakers, MA: } \\
8 \text { and } 25 \text { ML, MA: } 7 \text { ) }\end{array}$ & $\begin{array}{l}\text { Cypriot Greek, } \\
\text { Cyprus }\end{array}$ & $\begin{array}{l}\text { Backward Digit } \\
\text { Span Task; Corsi } \\
\text { Blocks Task; } \\
\text { Soccer Task; Si- } \\
\text { mon Task; } \\
\text { Switching Test }\end{array}$ & $\begin{array}{l}\text { MTL advantage over } \\
\text { ML; Bilectal advantage } \\
\text { over ML, but it was } \\
\text { smaller that the MTL } \\
\text { one and conditioned on } \\
\text { language proficiency }\end{array}$ \\
\hline $\begin{array}{l}\text { Clare et al. } \\
(2016)\end{array}$ & $\begin{array}{l}\text { Older adults }(50 \mathrm{BL} \text {, } \\
\text { MA: } 74 \text { and } 49 \mathrm{ML} \text {, } \\
\text { MA: } 73 \text { ) }\end{array}$ & $\begin{array}{l}\text { Welsh, Wales } \\
\text { (UK) }\end{array}$ & $\begin{array}{l}\text { Several standard- } \\
\text { ized neuro- psy- } \\
\text { chological tests, } \\
\text { e. g the Simon } \\
\text { Task }\end{array}$ & $\begin{array}{l}\text { No BL advantage. } \\
\text { Where differences are } \\
\text { observed, these tend to } \\
\text { favour ML }\end{array}$ \\
\hline $\begin{array}{l}\text { Wu/Zhang/G } \\
\text { uo (2016) }\end{array}$ & $\begin{array}{l}\text { Adults ( } 24 \text { bilectals, } \\
\text { MA: } 20 \text { and } 24 \text { ML, } \\
\text { MA: } 21)\end{array}$ & $\begin{array}{l}\text { Southern-Min } \\
\text { dialect, China }\end{array}$ & $\begin{array}{l}\text { Classic Flanker } \\
\text { task }\end{array}$ & No BL advantage \\
\hline $\begin{array}{l}\text { Bosma et al. } \\
(2017)^{3}\end{array}$ & $\begin{array}{l}\text { Children (120 BL, A: } 5 \\
\text { to } 6,6 \text { to } 7,7 \text { to } 8)\end{array}$ & $\begin{array}{l}\text { Frisian, } \\
\text { Netherlands }\end{array}$ & $\begin{array}{l}\text { Sky search Task; } \\
\text { Flanker Task; } \\
\text { Backward; Digit } \\
\text { Span task and } \\
\text { Backward Dot } \\
\text { Matrix task }\end{array}$ & $\begin{array}{l}\text { Intensity of exposure to } \\
\text { Frisian, mediated } \\
\text { by language balance, had } \\
\text { an impact on one of the } \\
\text { attention tasks only }\end{array}$ \\
\hline $\begin{array}{l}\text { Ross/ } \\
\text { Melinger } \\
(2017)\end{array}$ & $\begin{array}{l}\text { Children (54 BL, speak- } \\
\text { ers of English and other } \\
\text { languages, MA: } 7 ; 48 \\
\text { BD, MA: } 7 . \text { and } 45 \mathrm{ML} \text {, } \\
\text { MA:7) }\end{array}$ & $\begin{array}{l}\text { Dundonian, } \\
\text { Scotland }\end{array}$ & $\begin{array}{l}\text { Simon Task; } \\
\text { Flanker Task; } \\
\text { Berg Card Sort- } \\
\text { ing Task }\end{array}$ & $\begin{array}{l}\text { No BD advantage. Bilin- } \\
\text { gual advantage only in } \\
\text { the Simon task (more ac- } \\
\text { curate than ML) }\end{array}$ \\
\hline $\begin{array}{l}\text { Antón/ } \\
\text { Careiras/ } \\
\text { Duñabeitia } \\
(2018)\end{array}$ & $\begin{array}{l}\text { Adults (90 BL, MA: } 22 \\
\text { and } 90 \text { ML, MA: } 22 \text { ) }\end{array}$ & Basque, Spain & $\begin{array}{l}\text { Flanker task; Si- } \\
\text { mon task; Verbal } \\
\text { Stroop task; Nu- } \\
\text { merical Stroop } \\
\text { task }\end{array}$ & $\begin{array}{l}\text { No general BL ad- } \\
\text { vantage (but bootstrap- } \\
\text { ping analyzes indicated } \\
\text { BL advantage in smaller } \\
\text { sample sizes) }\end{array}$ \\
\hline $\begin{array}{l}\text { Oschwald et } \\
\text { al. }(2018)^{4}\end{array}$ & $\begin{array}{l}\text { Adults (26 BD, MA: 23; } \\
24 \text { similar BL, MA: 22; } \\
24 \text { dissimilar BL, MA: } \\
23 \text {; } \\
25 \text { ML, MA: 24) }\end{array}$ & $\begin{array}{l}\text { Swiss German } \\
\text { dialect, } \\
\text { Switzerland }\end{array}$ & $\begin{array}{l}\text { Flanker task; Si- } \\
\text { mon task }\end{array}$ & $\begin{array}{l}\text { No BL nor BD ad- } \\
\text { vantage }\end{array}$ \\
\hline $\begin{array}{l}\text { Poarch/ } \\
\text { Vanhove/ } \\
\text { Berthele } \\
(2019)\end{array}$ & $\begin{array}{l}\text { Adults ( } 34 \text { BD, MA: } \\
23 \text { ), whose performance } \\
\text { was assessed by lan- } \\
\text { guage dominance }\end{array}$ & $\begin{array}{l}\text { Germany, Swa- } \\
\text { bian }\end{array}$ & $\begin{array}{l}\text { Flanker task; Si- } \\
\text { mon task. }\end{array}$ & $\begin{array}{l}\text { Swabian-dominant BD } \\
\text { showed smaller flanker } \\
\text { and } \\
\text { Simon effects than } \\
\text { balanced German-Swa- } \\
\text { bian BD }\end{array}$ \\
\hline
\end{tabular}

Table 1: International studies concerning the effects of bilingualism on executive functions in speakers of minority languages 5

\footnotetext{
${ }^{3}$ The study was longitudinal; the same group of children were evaluated three times over the course of three years. The age ranges presented refer to each evaluation, respectively.

${ }^{4} \mathrm{BL}$ with an L2 from the Indo-European language family were classified as "similar BL" and BL with an L2 from a Non-Indo-European language family were classified as "dissimilar BL

${ }^{5}$ Legend: BD: Bi(di)alectals; BL: Bilingual; ML: monolingual; MTL: multilingual; MA: mean age of participants in years, rounding down in case of extra months; A: age of participants, in years, rounding down; RT: reaction $\rightarrow$
} 
The 16 papers we selected will be further discussed in regard of (1) participants' age and socioeconomic (SES) status; (2) the tasks used; (3) the minority language's context of use; (4) main outcome of the study.

\subsection{Participants' age and socioeconomic status (SES)}

Age and SES of participants can influence the results and are inclusion criteria for selecting the sample. The participants from this set of studies originated from many different areas, which means that their background across studies was variable. Almost all studies were conducted in Europe, with only one study carried out in China. It is known that the use of the minority language is widespread in most target regions, i. e. participants are immersed in a bilingual/bi(dia)lectal society (e. g. Catalonia, Switzerland, Basque Country and Sardinia).

Regarding age, half of the studies were conducted with children. The other studies investigated executive functions in adult (6) and elderly (3) bilinguals. It is not surprising that the studies conducted with minority languages outside Brazil have investigated predominantly children. Bialystok et al. (2004) argue that the bilingual advantage may be more easily found in groups other than adults, because in this group bilingualism would not result in a significant advantage. In adulthood, cognitive skills are at their peak performance, and bilingualism may not compensate for any deficits. Moreover, the concentration of the European studies in children indicates that the minority languages are in use by the overall population.

The occupation of adults was not always mentioned, but most participants were students. Older participants were mostly retired. Some children were recruited in bilingual schools in the Basque Country (Antón et al., 2014; Duñanbeitia et al., 2013); while children in the other studies were recruited in the context of a bilingual/bilectal society, but not in a bilingual school. In general, the studies also controlled immigrant status, which is a variable that can influence results (cf. Antón et al., 2018). In most of the studies with children, SES was controlled by asking parents to provide information on their occupation.

A detailed description of participants' SES was not always provided. In some studies (e. g. Costa/Hernández/Sebástian-Gallés 2008), there is no information about SES. It is very important to control this variable, as it has been often correlated with a better performance in executive functioning tasks (Antón et al. 2016). According to Ross/Melinger (2017), controlling participant characteristics (such as SES, IQ and language proficiency) should reduce noise in results. The measures of SES were not always mentioned, but some studies used a score based on education and occupation (de Bruin/Bak/Sala 2015; Antoniou et al. 2016), whereas other studies used the total monthly income divided by the amount of household members (Antón et al. 2018) or not mentioned the measures.

\subsection{Tasks used}

The European studies and the Chinese one applied standardized psychological tests for measuring executive functions. Tasks used in studies with majority language speakers (cf. Hilchey/Klein 2011) are replicated in the studies with minority language speakers, i. e. mainly

time. The term "bidialectal" or "bilectal" refers to speakers of two languages with significant typological similarity. Example: two varieties, or dialects, of Greek. 
Simon Task, Stroop Task and Attention Network Task. Researchers applied different versions of the tasks, in regard to the stimuli types (arrows, words, letters, numbers) and the age of the participants. In such tasks, the participants are asked to focus on particular stimuli, while inhibiting the irrelevant ones. It is interesting to notice that most studies applied more than one task, so that results of both or more experiment can be compared and correlated for supporting or not a bilingual advantage (cf. Paap/Greenberg 2013).

Moreover, only in some studies, the researchers applied tasks that relate to complexity of the executive functions, by applying tasks that tackle into shifting, updating and inhibition (Miyake et al. 2000). The studies of Gathercole et al. (2014) and de Bruin/Bak/Sala (2015), for example, applied respectively the Card sort task and a Task-switching experiment, for testing shifting, and the Simon task, an experiment of updating and inhibition. Paap/Johnson/Sawi's (2015) consider this practice especially important for investigating EF as a whole.

In the studies analyzed, most tasks use non-linguistic stimuli. These experiments may have to do with the aim of the studies with majority language speakers, i. e. to identify positive effects of speaking two (or more languages) on cognition. When the studies have linguistic tasks, they measure other constructs such as vocabulary (Lauchlan/Parisi/Fadda 2013). The studies should investigate the effects of bilingualism/multilingualism with linguistic tasks, because these tasks simulate linguistic processing.

\subsection{Minority language context of use}

This set of studies includes mostly European languages; with only one study involving speakers of a Chinese minority language. However, the languages vary with respect to their status and context of use, and not all studies have detailed information about these parameters. Since there seems to be no consistent evidence suggesting that language similarity directly impacts the effects of bilingualism/bilectalism on EF, for this paper it was deemed reasonable to include studies with bi(dia)lectals. Both minority languages and dialects share characteristics that are relevant to the proposed analysis, and as such including studies with dialects could provide valuable insights. Moreover, researchers do not always agree on the difference between dialect and minority languages.

Catalan, Basque and Welsh are official languages in the regions they are spoken and are used by the participants in their everyday lives. These languages benefit from language policies that aim to equate the status of the country language with the region language, given the importance of both languages to the identity of locals. For example, the bilingual children who took part of Antón et al. (2014)'s study were attending bilingual schools where both languages were used as vehicular languages.

Scottish Gaelic and Sardinian, according to Lauchlan/Parisi/Fadda (2013), are spoken by an increasingly small proportion of the respective populations (Scotland and Sardinia). Moreover, according to the authors, both regional governments have introduced legislation to promote and help preserve their respective minority languages. However, only Scottish Gaelic is taught in schools in his written form. This status influences both use and competence. The Sardinian children e. g. did not have a similar level of command of the Sardinian language in both oral and written form, when compared to Italian. Most speakers of Standard Italian consider 
Sardinian to be a dialect of Italian and the nearly $70 \%$ of the Sardinians may speak the local language (Garrafa/Beveridge/Sorace 2015).

Another language use context is diglossia or bilectalism. In Cyprus, Cypriot Greek is the local vernacular, acting as the low variety, and Standard Modern Greek, forming the high variety, i. e. the official, constitutionally recognized language and used in formal situations (Antoniou et al. 2016). A similar context is described by Oschwald et al. (2018): Swiss German is the low variety and Standard German is the high variety.

Moreover, other language varieties or dialects from China, the Netherlands, Scotland and Germany were investigated. Some of these languages have been recognized by the government, e. g. Frisian, which is taught for at least $1 \mathrm{~h}$ per week and in many schools and is used as one of the languages of instruction (Bosma et al. 2017). All these languages may be spoken in informal and oral contexts, and the number of speakers might be more reduced than the other languages reported in this paper.

\subsection{Main outcomes}

Studies found mixed results concerning a bilingual, bilectal or multilingual advantage in EF. Only four (from 16) studies found an advantage (Antoniou et al. 2016; Costa/Hernández/Sebastian-Gallés 2008; Garraffa/Bedveridge/Sorace 2015; Lauchlan/Parisi/Fadda 2013). Moreover, in four studies, the researchers found an advantage related to a subcomponent of executive functions (Bosma et al. 2017), a task (Ross/Melinger 2017), the sample size (Antón/Carreiras/Duñabeitia 2018) or balanced bilingualism (Poarch/Vanhoeve/Berthele 2019).

The reasons of an advantage are well known, as we revised in the section 2. Therefore, we consider important to review some aspects related to the absence of an advantage. Although participants of all studies use (and switch between) two (or more) languages in their daily lives and are compared to matched monolingual peers, there are unsuccessful replications of the bilingual advantage. The absence was found in studies with all age groups (children, adults and seniors).

The results are explained in various ways. Duñabeitia et al. (2014), Antón et al. (2014) and Gathercole et al. (2014) argue about the lack of an advantage mainly over the number of participants, i. e. the advantage would only appear in small samples. Their studies included samples larger than 300 participants. Even in those studies that applied two tasks, there was neither an inhibitory effect nor an overall Stroop effect in any variable of the tasks. According to Antón et al. (2014), the absence of an advantage found in their study adds to a growing body of evidence showing that most forms of bilingual advantage in tasks exploring attention (or EF) skills may be the result of uncontrolled factors (e. g. SES, socio-cultural diversity, immigrant status, educational level, mental activity cognitive or linguistic factors, among others) or specific conditions associated with the design and procedure of the experiments. The other studies of Antón and colleagues confirm this assumption. However, in Antón/Carreiras/Duñanbeitia (2018), the author conducted a bootstrapping analysis with randomly sampled subsets of 25,50 , and 75 participants, 1000 times for each sample size, and measured how often the EF were significantly different between groups. Then, they explored how often the sociodemographic variables differed significantly in those samples where the EF differences were found. The results of the 
additional analysis indicated that the bilingual advantage might indeed be caused by spurious uncontrolled factors rather than bilingualism itself.

One such factor that needs to be controlled is immigrant status. De Bruin/Bak/Sala (2015) controlled immigrant status, i. e. if the participants were immigrants or not. Studies have shown that this cultural variable plays a role in the experimental outcomes. The authors emphasize the importance of ensure that language groups only differ in terms of the languages that they speak.

Additionally, the use and knowledge of other languages, such as English, should be included as a factor to be controlled. Wu/Zhang/Guo (2016) did not find differences between monolectal and bilectal participants. However, both groups are bilinguals, because college students in China must learn English as their second language from junior high school. Therefore, the addition of a dialect, which is not a language used in writing, does not result in advantage on executive functions. They suggest that speaking two dialects of one language does not enhance EF. However, Antoniou et al. (2016) found a advantage of bilectal children over monolingual ones, but the multilingual advantage was bigger.

Interestingly, in a study (Clare et al. 2016), the researchers found no bilingual advantage of older Welsh bilinguals, but when there were differences, they tended to favour monolingual participants. The most plausible explanation may lie in the nature of the language use and its influence on cognitive processing in the bilingual group. For this bilingual group, language use is a more automatic and less effortful process than it would be for L2 bilinguals (a group often evaluated in other studies about bilingual advantage), and lexical competition may be less frequently experienced than is the case for L2 bilinguals, so that fewer demands are placed on EF. Moreover, slower lexical access and smallest vocabulary size can influence the little worst performance of bilinguals.

As we can see, the performance of different bilingual, bilectal and multilingual populations are analyzed in the studies. Oschwald et al. (2018) compared the outcomes of German monolinguals, bilectals (German and Swiss-German), close bilinguals (German-English) and distant bilinguals (German-Turkish) in inhibitory control and selection tasks. Results were ambiguous and supported a null effect hypothesis. Additionally, Ross/Melinger (2017) argue that there have been studies both with similar-language pairs, such as Catalan/Spanish (Costa et al. 2009) and unrelated such as English/Gaelic (de Bruin/Bak/Sala 2015) sustaining a advantage with no significant distinctions as to the magnitude of an EF advantage. Moreover, Bosma et al. (2017) and Poarch/Vanhoeve/Berthele (2019) found a little advantage mediated by language balance. Therefore, they suggest that future research may access more accurately the exposure and usage patterns, particularly of the minority language of bilinguals and bilectals.

\subsection{General discussion}

It is very difficult to propose generalizations based on the outcomes of the analyzed studies with regards to bilingualism/bilectalism/multilingualism with minority languages. The main reason for that are mixed results, variability in the target population groups, and the presence of uncontrolled factors. The fact that the studies do not form an internally consistent and homogenous group should come as no surprise. A consequence of this, however, is that potential underlying causes for the lack of an advantage are harder to track. 
Important additional factors that were not initially accounted for in our analysis were immigrant status and sample size. While the first contributes to the array of social and cultural variables that need to be taken into consideration, the second indicates a potential issue with method: most studies are conducted with relatively small samples, which might not reflect the overall populations.

The search for common underlying causes for the lack of a bilingual advantage in studies with minority language is hindered by the mixed results, uncontrolled factors, and the group's internal variability. Nonetheless, there are some considerations to be made.

There are significant problems with the evaluation of exposure, proficiency and context of use of the target minority language. One problem associated with that is the absence of standardized proficiency tests and evaluations for minority languages. This leads to vague and inconsistent information on the topic. Standardized questionnaires about the use of the language are vital to elucidate whether different patterns of use could be impacting individual results.

Social variables, such as SES, immigrant status, occupation and educational levels should also be more comprehensively assessed. Differences in social and cultural aspects across studies indeed hinder the possibility of replicating studies in different circumstances. However, when tackling languages that are so strongly defined by their social and cultural status, control of these variables becomes more important.

The combined data from the studies indicates the need for a more comprehensive list of social, linguistic and cultural variables to be controlled, as well as potential issues in method. At present, it is not possible to precisely trace the presence or absence of a bilingual advantage in speakers of minority languages to specific factors.

\section{$6 \quad$ Final remarks}

The study of the cognitive effects of bilingualism in speakers of minority languages is still incipient and comparatively more recent than that with speakers of widely spoken languages. This paper aimed at providing an overlook of state-of-the-art literature on the topic, as well as discussing the findings regarding recent discussions about the bilingual advantage.

The specific characteristics of minority languages could provide insight as to whether contextual or use-related factors are critical for the bilingual advantage to arise. However, going back to the main questions of this study, it becomes clear that there are no conclusive answers in sight. Evidence of a bilingual advantage in studies with minority languages is inconsistent. Furthermore, the corpus of studies is highly heterogeneous, making it more difficult to establish which individual factors could be responsible for the lack or presence of an advantage in executive functions.

The data discussed in this paper points to the need of greater control of social variables across groups, as well as more precise ways to measure exposure and usage of the minority language in future empirical studies. Numerous factors should be considered: SES and educational level of participants, scope and modality of minority language use, level of proficiency, proficiency in additional languages, ecological validity of tests, and cognitive and developmental aspects. Indeed, some of the aspects listed are particularly difficult to account for when dealing with languages that lack standardized or written forms. Additionally, the reduced number of speakers 
of minority languages and the potentially restricted age range also poses a problem for largescale testing.

Despite these obstacles, studies with minority languages can still provide important insights. Bilingualism is highly variable, and it is necessary to account for that variability in studies. While the numerous variables pose challenges to analysis and to the isolation of determinant factors, studies with languages in different contexts are essential if we are to arrive at an understanding of the bilingual advantage that is not restricted to a very limited set of conditions.

\section{References}

Allardt, Erik (1984): "What constitutes a language minority?". Journal of Multilingual and Multicultural Development 5: 195-205. doi.org/10.1080/01434632.1984.9994151.

Altenhofen, Cléo Vilson (1996): Hunsrückisch in Rio Grande do Sul. Ein Beitrag zur Beschreibung einer deutschbrasilianischen Dialektvarietät im Kontakt mit dem Portugiesischen. Stuttgart: Steiner.

Altenhofen, Cléo Vilson (2013): "Migrações e contatos linguísticos na perspectiva da geolinguística pluridimensional e contatual”.Revista Norte@mentos 6: 31-52.

Altenhofen, Cléo Vilson (2017): "Variedades de Línguas de Imigração Alemã no Brasil e Bacia do Prata”. Projeto ALMA-H. www.ufrgs.br/projalma/variedades-do-alemao [25.09.2020].

Altenhofen, Cléo Vilson et al. (2007): Fundamentos para uma escrita do Hunsrückisch falado no Brasil. Revista Contingentia 2: 73-87.

Altenhofen, Cléo Vilson/Frey, Jaqueline (2006): „Das bresilionische Deitsch unn die deitsche Bresilioner: en Hunsrickisch Red fo die Sprocherechte“. Revista Contingentia 1: 39-50.

Antón, Eneko et al. (2014): "Is there a bilingual advantage in the ANT task? Evidence from children”. Frontiers in Psychology 5: 1-12. doi.org/10.3389/fpsyg.2014.00398.

Antón, Eneko et al. (2016): "Does bilingualism shape inhibitory control in the elderly?". Journal of Memory and Language 90: 147-160. doi.org/10.1016/j.jml.2016.04.007.

Antón, Eneko/Carreiras, Manuel/Duñabeitia, Jon Andoni (2018): “The impact of bilingualism on executive functions and working memory in young adults“. bioRxiv: 449827. doi.org/10.1101/449827.

Antoniou, Kyriakos et al. (2016): „The effect of childhood bilectalism and multilingualism on executive control". Cognition 149: 18-30. doi.org/10.1016/j.cognition.2015.12.002.

Barkley, Russel (2012): Executive Functions: What they are, how they work, and why the evolved. New York: Guilford Press.

Bialystok, Ellen (2001): Bilingualism in Development: Language, Literacy, and Cognition. Cambridge: Cambridge University Press. doi.org/10.1017/CBO9780511605963.

Bialystok, Ellen et al. (2004): „Bilingualism, Aging, and Cognitive Control: Evidence From the Simon Task". Psychology and Aging 19: 290-303. doi.org/10.1037/0882-7974.19.2.290.

Bialystok, Ellen/Craik, Fergus/Luk, Gigi (2008): „Cognitive control and lexical access in younger and older bilinguals". Journal of Experimental Psychology: Learning, Memory, and Cognition 34: 859-873. doi.org/10.1037/0278-7393.34.4.859.

Billig, Johanna (2009): Bilinguismo e envelhecimento: efeitos no controle cognitivo. Porto Alegre: Universidade Federal do Rio Grande do Sul. 
Billig, Johanna Dagort (2014): Impacto do bilinguismo nas redes de atenção, no acesso lexical e na memória de trabalho em adultos. Universidade Federal do Rio Grande do Sul.

Bosma, Evelyn et al. (2017): „The Minimal and Short-Lived Effects of Minority Language Exposure on the Executive Functions of Frisian-Dutch Bilingual Children". Frontiers in Psychology 8: 1-12. doi.org/10.3389/fpsyg.2017.01453.

Brentano, Luciana (2011): Bilinguismo escolar: uma investigação sobre controle inibitório. Porto Alegre: Universidade Federal do Rio Grande do Sul.

Chin, Bee Ng/Wigglesworth, Gillian (2007): Bilingualism. An Advanced Resource Book. New York: Routledge. doi.org/10.4324/9780203410264.

Clare, Linda et al. (2016): „Executive control in older Welsh monolinguals and bilinguals”. Journal of Cognitive Psychology 28: 412-426. doi.org/10.1080/20445911.2016.1148041.

Coseriu, Engenio (1982): Sentido y tareas de la dialectología. Cuadernos de Linguistica. México D. F.: Universidad Nacional Autónoma de México.

Costa, Albert et al. (2009): „On the bilingual advantage in conflict processing: Now you see it, now you don't". Cognition 113: 135-149. doi.org/10.1016/j.cognition.2009.08.001.

Costa, Albert/Hernández, Mireia/Sebastián-Gallés, Núria (2008): „Bilingualism aids conflict resolution: Evidence from the ANT task“. Cognition 106: 59-86. doi.org/10.1016/j.cognition.2006.12.013.

Council of Europe (1999): „European charter for regional or minority languages“. Nationalities Papers 27: 139-155. doi.org/10.1080/009059999109235.

de Bruin, Angela/Bak, Thomas H./Della Sala, Sergio (2015): „Examining the effects of active versus inactive bilingualism on executive control in a carefully matched non-immigrant sample“. Journal of Memory and Language 85: 15-26. doi.org/10.1016/j.jml.2015.07.001.

Duñabeitia, Jon Andoni et al. (2014): The inhibitory advantage in bilingual children revisited: Myth or reality? Experimental Psychology 61(3): 1-18. doi.org/10.1027/1618-3169/ a000243.

Duñabeitia, Jon Andoni/Carreiras, Manuel (2015): „The bilingual advantage: Acta est fabula?”. Cortex 73: 371-372. doi.org/10.1016/j.cortex.2015.06.009.

Garraffa, Maria/Beveridge, Madeleine/Sorace, Antonella (2015): „Linguistic and Cognitive Skills in Sardinian-Italian Bilingual Children“. Frontiers in Psychology 6: 1-15. doi.org/10.3389/fpsyg.2015.01898.

Gathercole, Virginia C. Mueller et al. (2014): „Does language dominance affect cognitive performance in bilinguals? Lifespan evidence from preschoolers through older adults on card sorting, Simon, and metalinguistic tasks“. Frontiers in Psychology 5: 1-14. doi.org/10.3389/fpsyg.2014.00011.

Gazzaniga, Michael/Ivry, Richard/Mangun, George (2014): Cognitive Neuroscience: The biology of mind. 4th ed. New York: W. W. Norton \& Company.

Green, David W. (1998): „Mental control of the bilingual lexico-semantic system“. Bilingualism: Language and Cognition 1: 67-81. doi.org/10.1017/S1366728998000133.

Grenoble, Lenore/Roth Singerman, Adam (2016): „Minority Languages“. Oxford Bibliographies Linguistic: $1-2$.

Grosjean, François (2008): Studying bilinguals. Oxford: Oxford University Press.

Haugen, Einar (2001): „Dialeto, língua, nação“. Norma Lingüística. Tradução d. São Paulo: Edições Loyola: 97-114. 
Hilchey, Matthew D/Klein, Raymond M. (2011): „Are there bilingual advantages on nonlinguistic interference tasks? Implications for the plasticity of executive control processes“. Psychonomic Bulletin \& Review 18: 625-658. doi.org/10.3758/s13423-0110116-7.

Hughes, Claire (2005): „Executive Function and Development“. In: Hopkins, Brian (ed.): Cambridge Encyclopedia of Child Development. Cambridge, Cambridge University Press: 313-316.

Kramer, Rossana (2011): Effects of bilingualism on inhibitory control and working memory: a study with early and late bilinguals. Florianópolis: Universidade Federal de Santa Catarina.

Lauchlan, Fraser/Parisi, Marinella/Fadda, Roberta (2013): „Bilingualism in Sardinia and Scotland: Exploring the cognitive benefits of speaking a 'minority' language". International Journal of Bilingualism 17: 43-56. doi.org/10.1177/1367006911429622.

Limberger, Bernardo Kolling (2014): O desempenho de bilíngues e multilíngues em tarefas de controle inibitório e compreensão auditiva. Porto Alegre: Pontifícia Universidade Católica do Rio Grande do Sul. doi.org/10.13140/RG.2.1.4437.4645

Limberger, Bernardo Kolling/Buchweitz, Augusto (2012): „Estudos sobre a relação entre bilinguismo e cognição: o controle inibitório e memória de trabalho“. Letrônica 5: 67-87.

Linck, Jared. A./Hoshino, Noriko/Kroll, Judith F. (2008): „Cross-language lexical processes and inhibitory control“". Mental Lexicon 3: 349-374. doi.org/10.1075/ml.3.3.06lin.

Miyake, Akira et al. (2000): „The Unity and Diversity of Executive Functions and Their Contributions to Complex 'Frontal Lobe' Tasks: A Latent Variable Analysis“. Cognitive Psychology 41: 49-100. doi.org/10.1006/cogp.1999.0734.

Oschwald, Jessica et al. (2018): „Bidialectalism and bilingualism: Exploring the role of language similarity as a link between linguistic ability and executive control“". Frontiers in Psychology 9: 1-22. doi.org/10.3389/fpsyg.2018.01997.

Paap, Kenneth R. et al. (2018): „Bilingual advantages in inhibition or selective attention: More challenges“. Frontiers in Psychology 9: 1-10. doi.org/10.3389/fpsyg.2018.01409.

Paap, Kenneth R./Greenberg, Zachary I. (2013): „There is no coherent evidence for a bilingual advantage in executive processing“. Cognitive Psychology 66: 232-258. doi.org/10.1016/j.cogpsych.2012.12.002.

Paap, Kenneth R/Johnson, Hunter A/Sawi, Oliver (2015): „Bilingual advantages in executive functioning either do not exist or are restricted to very specific and undetermined circumstances“. Cortex 69: 265-278. doi.org/10.1016/j.cortex.2015.04.014.

Pasikowska-Schnass, Magdalena (2016): „Regional and minority languages in the European Union“. European Parliamentary Research Service: 1-12.

Peal, Elizabeth/ Lambert, Wallace (1962): „The relation of bilingualism to intelligence“. Psychological Monographs: General and Applied 76/27: 1-23. doi.org/10.1037/h0093840.

Pinto, Léa Maria Coutinho (2009): A relação entre bilinguismo e os processos executivos no envelhecimento. Porto Alegre: Centro Universitário UniRitter.

Poarch, Gregory J./Vanhove, Jan/Berthele, Raphael (2019): „The effect of bidialectalism on executive function“. International Journal of Bilingualism. doi.org/10.1177/1367006918763132. 
Ross, Josephine/Melinger, Alissa (2017): „Bilingual advantage, bidialectal advantage or neither? Comparing performance across three tests of executive function in middle childhood“". Developmental Science 20: 1-21. doi.org/10.1111/desc.12405.

Sanchez-Azanza, Victor A. et al. (2017): „Is bilingualism losing its advantage? A bibliometric approach“. PLOS ONE 12. e0176151. doi.org/10.1371/journal.pone.0176151.

Souza, Cristina Andréia/Damke, Ciro (2014): „Preservação de língua e cultura alemãs e políticas públicas: o que dizem os falantes?”. Revista Socioleto 5: 332-352.

Steffen, Joachim/Altenhofen, Cléo Vilson (2014): „Spracharchipele des Deutschen in Lateinamerika: Dynamik der Sprachvernetzungen im mehrsprachigen Raum“. Zeitschrift für Dialektologie und Linguistik 81: 34-60.

Wu, Yan Jing/Zhang, Haoyun/Guo, Taomei (2016): „Does Speaking Two Dialects in Daily Life Affect Executive Functions? An Event-Related Potential Study“. PLOS ONE 11. e0150492. doi.org/10.1371/journal.pone.0150492. 